\title{
Liminal Lives: Navigating the Spaces Between (Poet and Scholar)
}

\author{
C. L. Clarke \\ University of Saskatchewan
}

\begin{abstract}
This paper focuses on the importance of narrative beginnings to narrative inquiry, arguing that an examination of narrative beginnings is essential to positioning the researcher within the research. Through a series of personal poems, I unpack the significance of my own autobiographical beginnings from a narrative perspective, and from my proposed research on life and learning on the edges of community. In this paper, I also highlight the efficacy of employing poetic representation within a narrative inquiry. Through poetic representation, I demonstrate the liminal nature of understanding field texts and interim field texts as determined by the context of the three-dimensional narrative inquiry space, encompassing temporality, sociality, and place.
\end{abstract}

Keywords: narrative inquiry; poetic representation; poetic inquiry; three-dimensional narrative inquiry space; marginalization; community; identity

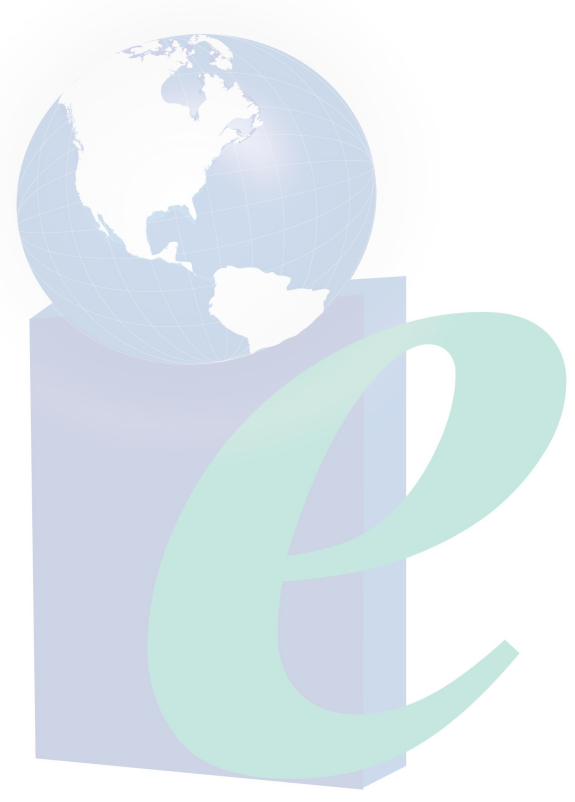




\section{Liminal Lives: Navigating the Spaces Between (Poet and Scholar)}

This paper takes up the question of what it means to inquire into our own narrative or autobiographical beginnings within a narrative inquiry. Specifically, I inquire into the use of poetic representation and poetic expression to explore the layers of autobiographical beginnings that inform the researcher's life as both a scholar and a poet. While autobiographical beginnings are only one aspect of narrative inquiry, they constitute an essential component to understanding our own place as researchers within a narrative inquiry. In this paper, I examine the importance of narrative beginnings or autobiographical beginnings to narrative inquiry. Through the demonstration of autobiographical beginnings expressed poetically, I argue that an examination of narrative beginnings is essential to positioning the researcher within the research. During the inquiry, the researcher, like the participants, is in a state of becoming. Autobiographical beginnings bring to the surface those factors influencing the researcher's perspectives, thus locating the researcher within the inquiry as well as within a larger life context. In addition to this primary focus of locating the researcher within the research through narrative beginnings, I demonstrate the efficacy of employing poetic representation and poetic expression within a narrative inquiry. Both narrative/autobiographical beginnings and the poetic representation of autobiographical beginnings highlight the liminal nature of the researcher's identity within an inquiry. My choice of poetic representation of autobiographical beginnings is not incidental or merely aesthetic. Poetic representation of autobiographical beginnings within a narrative inquiry is a rigorous and effective means of articulating the researcher's location while, at the same time, recognizing how the shifting nature of identity requires a revisiting of the researcher's perspective to remain connected to the ways in which the narrative inquiry continuously reshapes the researcher's understandings. In narrative inquiry, this process unfolds over the course of an inquiry through the telling, retelling, and reliving of the narratives. Through the poetry shared in this paper as well as the unpacking of the poetry, I demonstrate a small piece of that cycle. The poetic representation already exists as a retelling of some of my own pivotal experiences, especially pertinent to a larger inquiry underway, examining the life and learning that occurs on the edges of community, spaces conventionally constructed as marginalized. My research is situated in my understanding of my experience. As part of a larger narrative inquiry, it attends to the conventions of narrative inquiry as a methodology (Clandinin \& Caine, 2013; Clandinin \& Connelly, 2000; Caine, Estefan, \& Clandinin, 2013) while employing poetic representation to express key moments in the researcher's experience. In my focus on retelling through poetry and the narrative unpacking of that poetry, I engage in a reliving of those experiences, as does the reader. I retell, and thus, relive my own experiences of exclusion, isolation, and perceived marginalization. Through this retelling and reliving of my own experiences related to life and learning on the edges of community, I demonstrate the essential nature of autobiographical beginnings to the deeper understanding of my research wondering about those spaces constructed as marginalized.

\section{Autobiographical Narrative Beginnings: Beginning With Who I Am}

Every day begins for me with writing. I read from the works of other writers and when some piece of what they have written resonates with me, I respond in my own writing to those ideas. Always, my writing returns to my life, to the specific, concrete details that make up my life, to the moments of wonder, the questions, the veiled answers that emerge through all this writing and thinking that comprise my intellectual life. Often, my wondering spirals down into the past, to the origins of my ideas that grew out of a particular moment or in a particular place. With each 
recollection, I am remade through the retelling of these moments in reflection, the rewriting of my own history repeatedly. Inevitably, these processes of reflection and recollection lead to poems. In the distillation of language into poetry, I find my truest expression of self and thought. This is who I am. Through poetry I relive the narratives of my life, and through that reliving I become who I am. Ontologically, this process is the basis for my identity as a poet. From a theoretical and methodological perspective, I recognize this process as a cycle of meaning making grounded in the tradition of narrative inquiry. At the same time, I employ poetic expression and poetic representation of my autobiographical beginnings in order to attend to my identity as both a scholar and a poet. In the liminal space between my identity as poet and my identity as scholar, I am able to inquire into ways in which these identities might converge to create richer opportunities for meaning making in my research.

Clandinin and Caine (2013) use the terms autobiographical or narrative beginnings to refer to the personal stories narrative inquirers explore to "make evident the social and political contexts that shaped our understandings" (p. 171). Clandinin and Connelly (2000) assert, "One of the starting points for narrative inquiry is the researcher's own narrative of experience, the researcher's autobiography" (p. 70). Clandinin and Connelly (2000) also say, "narrative beginnings of our own livings, telling, retellings, and reliving help us deal with questions of who we are in the field and who we are in the texts that we write on our experience of the field experience" (p. 70). In other words, inquiring into our own narrative beginnings is essential to any research endeavor. Examining our own stories along with the stories of our research participants is essential to understanding the identity-making process. Because I am a narrative inquirer, I attend to my autobiographical beginnings in order to understand myself better as I enter into research alongside my participants. At the same time, I recognize a strong sense of self that identifies as a poet and requires poetic expression as part of those narrative autobiographical beginnings. Leggo (2010) states, "For stories to be creatively effective, they need to be shaped generatively and generously" (p. 68). He recognizes the need to attend to the multiple facets of our identities as researchers when he asserts, "We need spaces for many kinds of research, including lifewriting research that focuses on narrative, autobiographical, fictional, and poetic knowing” (Leggo, 2010, p. 68). As Leggo suggests, my autobiographical beginnings are both narrative and poetic. I examine the space between my identity as scholar and my identity as poet by sharing four original poems describing key experiences in my own life that shaped my identity and continue to resonate through my research wonders.

\section{In the Middle of the Muskeg: Locating Myself Within the Inquiry}

\section{Muskeg}

I listened in the night

through the fog of dreams

to the world asleep

and not asleep

around me.

In the back gabled bedroom 
one narrow window looked out

over the garage, dark paneling

the smell of moth balls

always cold floors.

The wire-springed bed frame

with the metal headboard

creaked when I breathed

and all I could do was breathe

and breathe

into the night

as I listened,

scurrying in the walls

relief when grey light

touched the edges of the window

long before sunlight burned

past the fire-blackened pine

and miles of Muskeg

behind the store.

A bulldozer once broke through the loam, Dad said

and sank until it was lost.

He said, No one knows how deep

the Muskeg is—so deep

it might go on forever.

We clung to a strip of gravel,

an atoll in a sea of Muskeg.

You couldn’t go anywhere.

There was nowhere to go-

our lives defined

by the gravel pad 
that kept us all from sinking

out of sight.

These days I don’t travel far from home.

I stay inside this room,

wonder if the rest of the world exists

or if I lie awake still afraid

surrounded by miles of Muskeg. (Clarke, personal writing, 2013)

In this poem, I express the sense of isolation and disconnection that permeated my life growing up in Northern Saskatchewan. The poem Muskeg is concretely situated in a place that actually existed. In the early seventies, the highway to La Ronge in Northern Saskatchewan was the only highway leading in and out of the North. When we first moved there, the road itself was unpaved. My parents' store perched on a gravel-reinforced lot at the junction of Highway \#2 and \#969, leading to Montreal Lake. On either side of the highway, except for the gravel pad where we lived, muskeg stretched for miles in every direction, creating both a geographical and metaphorical barrier to movement.

Clandinin and Caine (2013) say "Place directs attention to places where lives were lived as well as to the places where inquiry events occur" (p. 167). Of all the places that I have lived in my life, why do my recollections constantly return to Timber Cove and life on the edge of the muskeg? The persistence of these memories indicates that the experiences lived out on the edge of the muskeg hold deeply rooted connections to the research wonders I carry with me today.

I first began to explore the themes of the poem Muskeg in January 2012, thinking about what part of my own life created an interest to understand the experience of marginalization. In

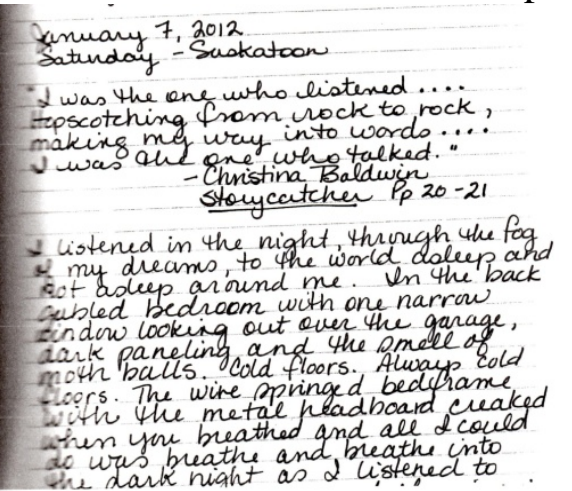
my journal writing, I reached back to a place where a sense of isolation and marginalization were most acute. I wrote about my experiences growing up in Northern Saskatchewan as someone transplanted into that landscape-a landscape that was, to me, foreign.

In retrospect, however, I realize that the landscape was not foreign, but rather I was foreign to the landscape. The poem, however, is a deeper expression of the recollection of being foreign to one's surroundings. Muskeg, in its temporal movement between the past and the present, connects the experiences of the poet as a child to the experiences of the poet as an adult- to the experiences of the poet as a researcher.

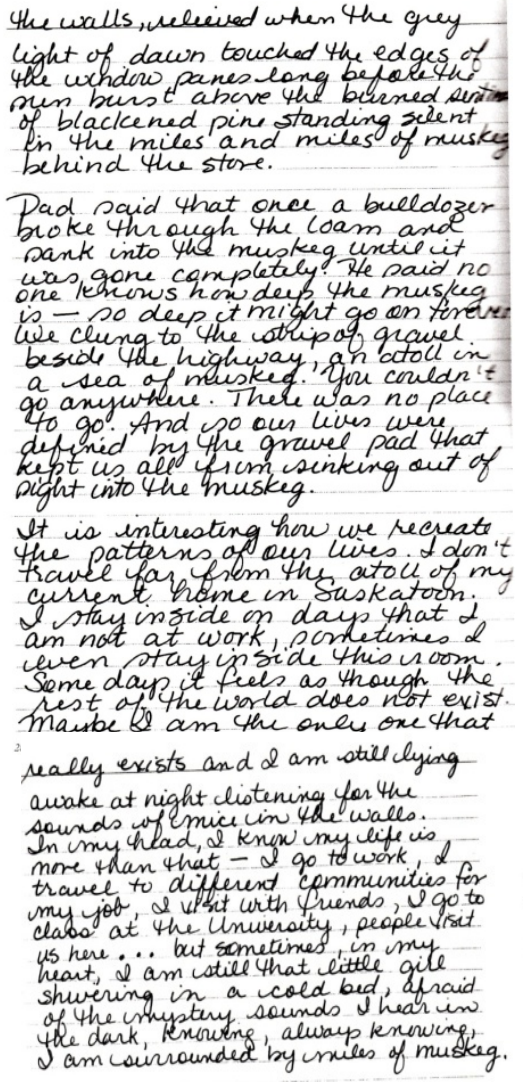


Methodologically, the poetic representation of those recollections reaches deeper than the recollections explicated in the journal entries. The poetic form more richly captures the complexity of those experiences that acted to shape my identity as a poet and that continue to shape my identity as a researcher.

Clandinin and Connelly (1992), drawing on the work of Schon (1979), assert, "metaphors are no mere 'anomalies of language' but are instead expressions of living” (Clandinin \& Connelly, 1992, p. 369). Clandinin and Connelly (1992) further assert the importance of metaphor in understanding teacher narratives, stating, "We and other teachers are, in an important sense, living our images and metaphors" (p.369). To understand Muskeg as illustrative of a moment in my "story to live by" (Connelly \& Clandinin, 1999), ${ }^{1}$ it is necessary to understand the metaphor of the muskeg that permeates this poem.

Muskeg is the Cree word for bog. The muskeg in the poem was a dangerous place because you could break through the thin layers of mossy soil and drown in the water below. In this way, the muskeg defined the place where I grew up as a negative space surrounding the small gravel island built up beside the highway that was solid enough to support the store with its living quarters upstairs. Furthermore, the muskeg in the poem represents the limitations that grow out of the fear of the unknown. The landscape described in the poem identifies the sense of limitation the poet as a young girl experienced while living so far away from anyone else. As a child, I remember the familial travelling in and out of communities that my parents identified as more valuable in relation to our home place on the gravel pad. Always, the muskeg was a benchmark for our lives in relation to other communities. As an adult, I recognize that Muskeg has become a benchmark for my research and autobiographical wonderings. When I was growing up beside the muskeg, we moved through the borders of inclusiveness and exclusiveness, our identities shifting as we travelled through each day and through each landscape. This movement through the borders of communities that I never seemed to belong to regardless of their make-up has created in me a persistent desire to understand more deeply the experience of being on the edges of community.

As I consider the experiences detailed in the poem Muskeg, I realize that this poem also recognizes the impact of the stories that parents tell to keep their children grounded to the same place, stories that limit their sense of agency and mobility, stories that work to keep them safe. The story of the bulldozer sinking into the muskeg was a cautionary tale told by my father to keep my siblings and me out of the muskeg, to keep us safe from harm. It accomplished more than that, though — for the longest time, it defined what was possible and what was not possible.

A landscape of limitation, defined by borders of fear, of isolation, and of the unknown, shaped my understanding of experience as also defined by limitation and marginalization. This definition of the landscape grew out of my experience as someone transplanted into the landscape instead of being a part of it. Furthermore, in my adult contemplations of the historical significance of our arrival and lives on the gravel atoll beside the muskeg, I recognize that we were settlers in the muskeg and lived with the settlers' mentality of mixing only with other settlers, not with those indigenous to the area. Perhaps our lives might have been less permeated by a sense of isolation and disconnection if we had allowed ourselves the community of the people indigenous to the area. Perhaps they might have taught us to view the landscape as less harsh or inhospitable if we had been open to cultivating community with those for whom the landscape was home. 
Not long ago I had the opportunity to share my musings on the Muskeg with a group of colleagues during a research retreat. In an astounding moment of serendipity, one of the research retreat participants shared that he, too, came from the area my poem describes. As we talked about the importance of this place to the development of my identity, this person shared a very different and much more positive experience of the muskeg. This sparked in me a wondering around whether or not and how our experiences of inclusion and exclusion might be, at least in part, a matter of perspective. What if that perspective provided an opportunity to shift? How might such a shift in perspective influence the identity making growing out of that experience of place?

My poem Muskeg describes not only a distinct location but also the passage of time and how the experiences of childhood reverberate through our adult selves. Furthermore, it clearly articulates the sense of isolation present in the researcher-poet's life-the feeling that the ability to interact socially was somehow impaired by a childhood spent living in isolation. These feelings and memories are integral to identity making, particularly my identities as researcher and poet. As someone who has lived in a space defined primarily by limitations, I am aware of the ways in which we limit others' experiences not only to define them but also to confine them within expectations. It is this understanding of my autobiographical beginnings as a researcherpoet, experienced through the writing and retelling of my poems, which heightens my interest in learning more about the ways in which life on the edges of community unfolds for others.

\section{Life on the Edges: Navigating the Changing Landscape of Autobiographical Beginnings}

\section{$\underline{\text { The Blue Dress }}$}

I remember the details

preserved like dried beans in a mason jar

one hundred and forty-five dollars a month

for the bachelor suite at Nesbit Apartments

half of what I made a month in my job

working the desk at the YWCA -

one room no bigger than a bedroom

kitchen in a closet and a bathroom

with a claw-foot tub

circa 1912 hardwood

three tall windows

facing West.

In the way back

before language 
every thought is an image

sealed in cellophane.

I am visiting my dad's mom

in an apartment with the same floors.

She wears a blue dress and sips Red Rose tea

beside the same three windows.

Something in her frown

and concrete chin

frightens me

so I never wear a blue dress -

only blue jeans and loose peasant blouses.

My bed is under the windows

to catch the scraps of breeze

lifting from burning asphalt -

downtown Prince Albert in the summer,

as big to me then as Los Angeles

or New York; big enough

to hide from change

two floors above

the street. (Clarke, personal writing, 2013)

The Blue Dress is a poem that, like Muskeg, captures the experience of living on the edges of community. It describes my memories and my living situation as a young woman who feared she would become like her grandmother whose life had always seemed confined within her small apartment with little prospect for interaction outside. Like Muskeg, this poem relies heavily on a sense of place and provides concrete images of the details that define that space. Less concrete, however, is the developing identity revealed within the poems, often through the juxtaposition of images rather than the explicit detailing of cause and effect. Here we see a grandmother through the eyes of a very young child whose impression is that she is rigid, unmoving, and ultimately unhappy. The child draws a connection between her grandmother`s sternness to the place where her grandmother lives as well as what she wears. Within the poem, however, a temporal shift occurs in which the past reaches forward to claim the present. The child, now grown, finds herself in the same or a similar apartment as the one that her grandmother lived in and despite the young woman's ritual act of never wearing a blue dress, she struggles to live a different story from her grandmother`s story. There is also a sense of 
unfolding awareness in the poem as the speaker realizes life in the apartment is both similar to and different from her grandmother's life. This sense of the familiar within the unfamiliar creates a moment in the woman's life where she is stuck in place-unable to enact change and move forward and unable to accept the life she is living.

As with the poem Muskeg, the apartment described in the poem is an actual place that I lived in when I was twenty-two. The descriptions in the poem of my apartment are as accurate as memory allows, not fictionalized nor, as far as I can recall, exaggerated. I also distinctly remember visiting my grandmother in a similar apartment when I was very young. Her apartment certainly was located within the same downtown neighbourhood. It may even have been within the same building, although that is somewhat unclear to me at this point. What is clear, however, are the emotions that persistently cling to the memory and the remembered determination to avoid my grandmother's solitary lifestyle. Grandma lived alone in that little apartment and I lived alone in my similar little apartment. It seemed to me then that my life was replicating the experiences I thought my grandmother had experienced. I viewed that as negative and in danger of defining who I would become in later adulthood. I cannot say specifically why this was so concerning to me. I recall that it was tied to the employment I had as the night receptionist at the YWCA, which provided only enough money to live on and not enough to change my life circumstances. My income certainly would have categorized me within the group of the working poor, but as a young woman this was an accepted income bracket. All of my friends who were not living at home were living in similar tiny apartments and reveling in their freedom. I was not reveling. I was wondering how I would keep myself from being trapped within that socioeconomic space and place forever. In The Blue Dress, both the child and her adult self demonstrate a complex mix of desire for change and fear of change. It is a position that the young woman in the poem experiences, that I experienced-a position that the woman must adopt due to circumstances - and it is a positioning, a space and place that the young woman chooses to remain in.

Socioeconomic status is one of the ways in which we define ourselves or can be defined by others. Terms such as poor, middle class, and affluent all serve descriptive purposes in relation to some more or less articulated norm. While it can be argued that these methods of defining people or groups of people are inherently constructions with no connection to the actual experiences and life circumstances of people, there can be no doubt that these overarching categories do have an influence on the ways in which people define themselves. These definitions, however close or far from reality they might be, are part of a landscape of identity making that emerges out of the experiences of people. In The Blue Dress, my younger self recognizes the starkness of her grandmother's apartment and connects it to her grandmother's identity as harsh and rigid. Rightly or wrongly, my younger self creates a causal relationship between the space/place and the identity of her grandmother. When she finds herself living in a strikingly similar space, she struggles to ensure that her identity development does not become indelibly influenced by the space.

In contemplating the themes and metaphors of The Blue Dress and Muskeg, I begin to wonder what part of our experiences might be externally generated and what parts might be internally endured or accepted? At what point do we begin to story ourselves in the ways that we are storied? Is it possible to mark the transition or, concomitantly, to resist the transition? Do people living and learning on the edges of community inevitably come to see themselves as marginalized? 
We experience The Blue Dress as a retelling. The speaker in the poem is looking back from some future that has escaped the apartment with the three windows facing west, just as the speaker in Muskeg escaped the gravel atoll. However, these escapes are not the foci of the poems. They are incidental, inferred, with the primary focus being on those experiences of isolation and marginalization, combined with a general wondering about the details that might comprise the experiences. Yet, as the poet, I no longer live either on the edge of the muskeg or in the apartment from The Blue Dress. I am not sure, however, if it is possible to view my movement out of the muskeg and out of the apartment as having escaped those places since their impact on my identity making and curriculum making remains. A part of me still experiences that sense of living on the edge of community explored in this poem. The experience of the experience (Clandinin \& Connelly, 2000) endures and informs my present experience.

As a an interim research text, ${ }^{2}$ based on field texts, both Muskeg and The Blue Dress function to focus the researcher-poet on both the experiences detailed in the poems and the experience of the poems, which is to say "field texts slide back and forth between records of the experience under study and records of oneself as researcher experiencing the experience" (Clandinin \& Connelly, 2000, p. 87). As I inquire into these interim research texts, I learn not only more about the experiences detailed there but also about myself now, as a researcher, inquiring into those experiences. The process is ongoing, without a stopping point. In this way, we are always in medias res-researchers, poets, and individuals in the middle of our stories to live by even as we pause to inquire into them.

\title{
Beyond the Edge: Crossing the Boundaries of Identity Within Autobiographical Beginnings
}

\author{
Old Road \\ Drift of exhaust \\ past apartments, vacant lots \\ dusty from too little rain \\ reminders of cool, green scrub brush grown thick (4) \\ among blackened stumps barely taller (5) \\ than my eleven-year-old head \\ blueberries warm with summer’s watching \\ always watching \\ for bears on the old road \\ to the dump. \\ One day \\ my brothers and I followed that road \\ past where it ended in a ditch
}


cut crossways to keep cars out.

We followed it through bush

thick as planted corn, sometimes

hardly a track amongst the spruce and poplar

until we burst out onto a highway (18)

surprising us, stranding us

up to our waists (20)

in Labrador Tea. (Clarke, personal writing, 2013)

The poem Old Road demonstrates the inward/outward/forward/backward movement of narrative inquiry (Clandinin \& Connelly, 1994; 2000):

By inward, we mean toward the internal conditions, such as feelings, hopes, aesthetic reactions, and moral dispositions. By outward, we mean toward the existential conditions, that is, the environment. By backward and forward, we refer to temporality - past, present, and future. . . to experience the experience - that is, to do research into an experience-is to experience it simultaneously in these four ways and to ask questions pointing each way. (Clandinin \& Connelly, 2000, p. 50)

In the beginning of Old Road, the perspective is from the present - the speaker is travelling in a vehicle, experiencing the smell of exhaust and noticing the urban landscape of apartments and vacant lots. The vegetation of the vacant lots reminds her of a different landscape and she moves temporally from the present to the past through her memories of the "scrub brush grown thick/among blackened stumps" (Old Road, lines 4-5). Not only does she move backward temporally but also she moves inward emotionally to recall her fear of watching for bears on the road leading to the dump.

The experience of moving inward and backward produces the recollection of a specific moment in the poet's life-the day she explored the old road with her brothers. The description of their experiences following the old road beyond the boundaries of their community — "past where it ended in a ditch/cut crossways to keep cars out” (Old Road, lines 2-3) — can be read literally. This is a description of a particular experience, a specific day, and a specific activity, even a specific landscape, through which the children traveled to discover what lay beyond their community.

At the same time, expressed poetically, the articulation of the experience invites us to think metaphorically about this experience as well. The children breached the boundary of their community to inquire into what might lay beyond. Metaphorically, this poem is an exploration of possibility, of what might exist outside of established boundaries, both in terms of experience and identity. It details the emotion associated with the act of stepping outside of established norms, moving beyond the borders or edges of a community. It is in the metaphorical contemplation of the experience of border crossing that the deeper meaning for the poet as an adult emerges. What is the meaning of the experience of venturing beyond the boundaries of their community? What might it mean in light of the descriptions and meanings provided in 
Muskeg and The Blue Dress? Taken as a suite of experiences, these poems suggest a deeper motivation at work in the experiences of the girl and her brothers. What, if anything, lay beyond the Muskeg?

At the end of Old Road, the trio "burst out onto a highway" (Old Road, line 18) as an unexpected outcome of their explorations. Their surprise prevents them from following the highway. The image of the trio stranded "up to our waists/in Labrador Tea” (Old Road, line 1920) suggests an inability to move beyond the known into the unknown. The analogy of being stranded up to their waists in Labrador Tea suggests the forces at work in the lives of individuals to persuade stasis, to keep a person in their comfort zone even if that comfort zone is not that comfortable. The Labrador Tea that surrounds them is a plant indigenous to the bush of Northern Saskatchewan muskeg. There it is both familiar and unfamiliar: it is a familiar plant often viewed by the children along the roadsides, and near their homes on the gravel pad and unfamiliar because they do not understand its use, its importance. In this sense, its potential remains a mystery. The Labrador Tea in the poem is a metaphor for the boundary the children must pass through to enter into a different community. The highway the children burst out upon is a surprise and represents the unfamiliar. The poem suggests that perhaps, for some, living and learning on the edges of community is more comfortable, more familiar than venturing beyond the edges or margins into the unknown. Certainly, the poetic representation of these experiences raises questions about the boundaries of communities, the forces that influence individuals to adhere to those boundaries or, concomitantly, to pass through them, and how the experiences of living and learning on the edges of community resonate through a person's life to create a metaphorical echo that repeatedly influences identity making. As Caine, Estefan, and Clandinin (2013) assert, "In a narrative inquiry, stories are not just a medium of learning, development, or transformation, but also a life” (p. 578). As we compose narratives, then, we are composed.

\title{
Living In-Between: Navigating Our Multiple Stories to Live By
}

\author{
Innocence \\ Before \\ there were Sunday suppers \\ spaghetti with meat sauce \\ brown bag lunches with smiling faces \\ soft green dresses \\ patent leather shoes - \\ white gloves for church \\ white socks for school.
}

Before

there were Halloween pillowcases filled with candy 
spruce trees heavy with tinsel

hand-kneaded doughnuts, wood stoves, tea.

Every bed made itself

every mitten found its mate

every afternoon started its own fire

to chase the chill away before supper.

I still look for smoke

rising from the chimney

a familiar face alive

in the kitchen window

as the bus pulls away

down the lane.

In this final poem of my autobiographical beginning, Innocence breaks from the previously discussed themes of marginalization and movement through the borders of community to capture a time in my life when there was narrative coherence in my experiences and all the details of those experiences reinforced a sense of belonging and safety. The irony of the poem, of course, is that it begins by looking back to a time of easy predictability, immediately suggesting that the landscape of belonging has shifted and grown into something decidedly different from the experiences detailed in the first two stanzas. Stanza 1 and Stanza 2 begin with the temporal benchmark of "Before" although we are never told "Before" what. As readers, we can assume an experience so significant that it makes the experiences detailed in the poem stand out in contrast. It is here that we see the effectiveness of using poetic representation as opposed to a prose narrative. In prose, there is an expectation to complete the thought, to tell or at least show the full story of what came before, what intervened, and what came after as the conventional form of a prose narrative. With poetry, it is possible to leave unspoken the intervening event, creating possibility for the reader to fill in the gaps with their own experience.

Anyone who knows me knows that the event of my mother's death when I was 17 years old stands as a benchmark for all other experiences in my life. This is the experience that the "Before" refers to without explicitly stating it. Interestingly, Innocence also describes a place, and the human components of that space, "before" the Muskeg. The scene depicted occurred as part of my childhood before we moved to the muskeg; however, 10 years later my mother passed away. From that perspective, "Before" could also refer to life before the muskeg. What we know from the details provided in the poem Innocence is that there was a coherence in the experiences of the poet prior to the life event and that the coherence of those experiences resonates through whatever came afterwards, so much so that she imagines arriving home to find the same wood smoke rising from the chimney and the same treasured person watching for her from the kitchen window. In the sense that this experience is imagined, it is a forward-looking story (Clandinin \& Connelly, 2000), one that imagines a reconstruction of narrative coherence in the poet- 
researcher's story to live by. At the same time, it holds within it the seed of a backward-looking story, the realization that the person she expects to see there will not be there. The past and the present exist at the same time in this narrative and through the images provided by the poet they vie for centrality. Together, the four poems (Muskeg, The Blue Dress, Old Road, and Innocence) individually and collectively provide a sense of from where the researcher-poet comes, from where I come-the experiences that shaped my identity and that resonate with me today, informing the relationships I develop with research participants and the insights and interpretations that grow out of those relationships.

Brady (2009) emphasizes the impossibility of remaining objective as a researcher. In quantitative research, data is said to speak for itself but, as Brady (2009) points out, "Nothing speaks for itself. Interpretation is as necessary to human life as breathing” (p. xi). Brady's expression of the researcher's involvement in interpreting data reminds me of Connelly and Clandinin's (2006) emphasis on the importance of autobiographical beginnings in narrative inquiry. Only when we begin to understand our own narrative beginnings do we situate ourselves positively toward understanding the personal and relational understandings that grow out of narrative inquiry.

Inquiring into our own narrative beginnings is essential to any research endeavor. At the same time, trying to maintain a professional distance from oneself as one attempts to make meaning of one's personal narratives leads to a sense of dividedness that is impossible to suppress. I find it difficult to separate or compartmentalize my understanding of self into the professional and the personal as conventional academic discourse suggests that we should. This is part of the reason why even in my research, poetry takes a prominent position. I cannot separate my identity as a poet from my identity as a researcher. The two co-exist in my work in the same way that they co-exist in my life. For me, being both a poet and a narrative inquirer means I live in the in-between space where creative expression and scholarly expression overlap. As Caine, Estefan, and Clandinin (2013) state: "These in-between spaces are filled with uncertainty and indeterminacy. They are places of liminality; the betwixts and betweens, which, we argue, require attention to context(s), relationship(s), and time to explore narratively" (p. 580). Like a Venn diagram, ${ }^{3}$ the deepening understanding of my stories and the stories of research participants grows from the spaces in-between creative expression and scholarly expression where the two circles overlap. In those spaces in-between from which the poetry emerges, a new community of understanding forms-a relational community defined by its overlapping borders while, at the same time, not confined by them. This wondering from a place of liminality is all part of a whole that wonders about life in general and seeks to make sense of life holistically, not one compartment at a time. The children who come into our classrooms also come with a holistic wondering about the world and about life as a whole, not just about the subjects we say are valuable or in the order and timelines that we present them. In this way, my inability to compartmentalize mirrors children's inability to separate themselves from their identity as student and their identities as daughters, sons, grandchildren, or whatever other identities they might hold.

As Trinh T. Minh-ha (1989) says, "Despite our desperate, eternal attempt to separate, contain, and mend, categories always leak” (p. 94). In the same way, the categories or compartments of our lives bleed together, one into the other, until they are indistinguishable as categories and become the liquid in a fluid process that flows from one moment to the next without interruption. As researchers who struggle to separate our own identities into categories, 
we recognize the inappropriateness of trying to do the same in our exploration of the identity making of our research participants, whether they are children or adults, in a school setting or elsewhere. Identity making is, by its very nature, complex and ongoing. Our explorations into identity making should reflect that complexity.

\section{A Return to the Beginning: Exploring the Researcher's Identity Within the Inquiry}

As I consider my own process of identity making and the importance of understanding my autobiographical beginnings, and as I enter into these explorations of identity making, I am reminded of the poem Walking at Brighton by Dave Margoshes (1988). In this poem, Margoshes (1988) explores the retrospective narrative of a speaker who recalls feeling on the edges of his familial community, "and I was a stranger in the family,/always walking behind where the view is different” (p. 16). I recognize the sentiment expressed in Margoshes’ poem of being a stranger within your own family. The community of my family was not a community in which I was comfortable. Like Margoshes' speaker, I seemed always to see things from a different perspective than my siblings or parents, suddenly and consistently bumping up against my difference and their difference even though on the surface we shared the same circumstances.

In my own family, I lived an experience of exclusion that Clandinin et al. (2010) detail in the context of dominant school narratives, where the exclusion of personal narratives excludes and discourages individuals from seeking connection with those who appear to fit into the dominant school narrative (p. 449). My sense of disconnect came not so much from a dominant cultural narrative in conflict with my identity as it did from a familial narrative that storied me as separate, as different. The identities that I carried with me, that I still carry with me, of feeling isolated and separate, apart from community, are integrally connected to my identity as a curriculum maker. They are present in the narratives that emerge from my life as well as in the moments shaped by interaction with colleagues and children. From my earliest days a binary of self and other was strongly established in my experience primarily through familial curriculummaking (Clandinin et al., 2006) moments. From my very earliest days through my own sense of not belonging to the community of my family, I began to question the dichotomous positioning of the centre and the edges of community. I began to wonder which, if any, group I belonged to or if, in fact, I might belong to both.

Clandinin et al. (2010) recognize, "Within the institutional landscape, claiming an identity can be more challenging than passively accepting one” (p. 473). I suggest it is not only in the institutional landscape but also in all landscapes, including the family, where identity making remains a complex and fragile process. In the midst of this fragile process, I wonder what happens when children's sense of themselves is under attack by a dominant narrative that does not fit coherently with their own. I wonder what it means in terms of identity making to be excluded so readily and so regularly that the only comfortable space is the space that excludes. What does it mean to identity making to recognize yourself as positioned on the outside looking in or, as Margoshes (1988) frames it, to "always be walking behind where the view is different" (p. 16)?

Dewey (1938) suggests context becomes the truths of a present experience, informing our understanding of narratives as we endeavor to unpack them. Jackson (1992) also supports an emphasis on context by arguing, "all experience is necessarily situational and contextualized, that there is no privileged position outside of experience from which to achieve a free and 
independent (i.e., non-contextualized) perspective” (p. 10). Jackson (1992) acknowledges the presence of bias in all forms of inquiry and research by stating, "We begin our search for answers already faced in one direction or another, our proclivities pre-established, our inclinations making us lean this way or that” (p. 20). Essentially, Jackson argues for recognition of a bias by the researcher rather than a futile attempt to claim objectivity and distance. If we examine the metaphor of facing in a particular direction, it becomes clear that we can only see what is within our field of vision-our perspectives, then, are metaphorically determined by the "field of vision" defined by the direction in which we look.

Jackson's (1992) recognition of probable bias fits well with Dewey's (1938) ideas about contextualized perspective. Together they assert that our perspectives never exist in a void but rather grow out of a context that turns in one direction or another prior to exploration. This is not to say that a person cannot turn around to face another direction. Jackson referred to our proclivity, preference, and context, intersecting to create a propensity for one position or another. In Jackson's (1992) words, "there can be no position outside interpretation, there is no noninterpretive stance. There are only ways of looking, a category that includes ways of looking at ways of looking” (p. 20). Here, Jackson nods to the multiple layers of exploration that inform our perspectives as we look and look at how we look-meta-narrative, so to speak. Our understandings, by their very nature, are at best personal interpretations.

\section{A Liminal Life: Both Poet and Scholar}

Why do we choose the threads we choose when we begin to unpack the field texts from our research? Why do we notice the things we then attend to? What is it in our own experiences that shape a particular research experience? Brady (2009) points out, "all research necessarily starts with an observer moving through the world as a personally-situated [sic] sensuous and intellectual being” (p. xi). As the four poems presented earlier demonstrate, each person, each researcher is personally situated. Our meaning making is inextricably bound up with our identity and the experiences that we have and carry with us. My own experiences of living in an isolated part of Northern Saskatchewan shaped my interest in understanding the human experience of marginalization, it motivated me to rethink the way I frame marginalization and to ask whether or not I might see that space as constructed through identity and experience-as something determined individually and organically as a result of my experiences. Although I have provided only four brief moments of my autobiographical beginnings expressed poetically, they capture the essence of what has driven me to ask questions about life and learning on the edges of community. Without exploring my own autobiographical beginnings, and without exploring them poetically, I would not understand as deeply as I do who I was, who I am, and who I am becoming. Furthermore, I would not have as deep an understanding of the factors related to my identity as a poet and scholar that not only bring me to these research wonders but also that press me forward through the larger inquiry itself. In an academy that so often encourages researchers to strip themselves of all identifying features, these poetic autobiographical beginnings are essential to understanding how I position myself within the narrative inquires in which I engage. They provide a contextual grounding for the foundational focus of the work that I do. Represented poetically, these narrative beginnings identify me not as either a poet or a scholar but as both a poet and a scholar. In this sense, I am no longer stranded up to my waist in Labrador Tea like the young girl in Old Road, but rather I have begun to cross the border out of the muskeg, to move through that boundary and into the community beyond. 


\section{References}

Brady, I. (2009). Foreword. In M. Prendergast, C., Leggo, \& P. Sameshima (Eds.), Poetic inquiry: Vibrant voices in the social sciences (pp. xi-xvi). Rotterdam, NL: Sense Publishers.

Caine, V., Estefan, A., \& Clandinin, D. J. (2013). A return to methodological commitment: Reflections on narrative inquiry. Scandinavian Journal of Educational Research, 57(6), 574-586.

Clandinin, D. J. (2013). Engaging in narrative inquiry. Walnut Creek, CA: Left coast Press, Inc.

Clandinin, D. J., \& Caine, V. (2013). Narrative inquiry. In A. Trainor \& E. Graue (Eds.), Reviewing qualitative research in the social sciences (pp. 166-179). New York, NY: Routledge.

Clandinin, D. J., \& Connelly, F. M. (1992). Teacher as curriculum maker. In P. W. Jackson (Ed.), Handbook of research on curriculum (pp. 363-401). New York, NY: Macmillan.

Clandinin, D. J., \& Connelly, F. M. (1994). Personal experience methods. In N. K. Denzin \& Y. Lincoln (Eds.), Handbook of qualitative research. Thousand Oaks, CA: Sage.

Clandinin, D. J., \& Connelly, F. M. (2000). Narrative inquiry: Experience and story in qualitative research. San Francisco, CA: Jossey-Bass.

Clandinin, D. J., Huber, J., Huber, M., Murphy, M. S., Pearce, M., Orr, M. M., Steeves, P. (2006). Composing diverse identities: Narrative inquiries into the interwoven lives of children and teachers. London, UK: Routledge.

Clandinin, D. J., Steeves, P., Yi, L., Mickelsoon, J. R., Buck, G., Pearce, M., Caine, V., Lessard, S., Desrochers, C., Stewart, M., \& Huber, M. (2010). Composing lives: A narrative account into the experiences of youth who left school early. Retrieved from http://www.research4children.com/data/documents/ComposingLivesANarrativeAccounti ntotheExperiencesofYouthwhoLeftSchoolEarlyFinalReportpdf.pdf

Connelly, F. M., \& Clandinin, D. J. (1999). Shaping a professional identity: Stories of education practice. New York, NY: Teachers College Press.

Connelly, F. M., \& Clandinin, D. J. (2006). Narrative inquiry. In J. Green, G. Camilli, \& P. Elmore (Eds.), Handbook of complementary methods in education research (pp. 477487). Mahwah, NJ: Lawrence Eribaum.

Dewey, J. (1938). Experience and education (pp. 33-50). New York, NY: Collier Books.

Jackson, P. (1992). Conceptions of curriculum and curriculum specialists. In P. Jackson (Ed.), Handbook of research on curriculum (pp. 3-40). New York, NY: MacMillan.

Leggo, C. (2010, Autumn). Lifewriting: A poet’s cautionary tale. Learning Landscapes, 4(1), 6784.

Margoshes, D. (1988). Walking at Brighton (pp. 16-17). Saskatoon, SK: Thistledown Press. 
Minh-ha, T. T. (1989). Woman, native, other: Writing postcoloniality and feminism. Bloomington, IN: Indiana University Press.

Schon, D. A. (1979). Generative metaphor: A perspective on problem—setting in social policy. In A. Ortony (Ed.), Metaphor and thought (pp. 254- 283). Cambridge, England: Cambridge University Press.

\section{Endnotes}

${ }^{1}$ The term stories to live by is a narrative term for identity used by Connelly and Clandinin (1999) to demonstrate the connection between narrative and identity.

${ }^{2}$ Clandinin and Connelly (2000) describe interim research texts as "texts situated in the spaces between field texts and final published research texts” (p.133). Clandinin (2013) explains interim research texts as a way for researchers to "continue to engage in relational ways with participants" (p. 47) as they begin the task of analysis of the field texts. Ideally, interim research texts are negotiated and even co-composed with the research participants as the researcher and participants determine together how best to create a research text that is both authentic and compelling (Clandinin, 2013). Interim research texts, therefore, can often be partial texts that move the ongoing interpretation from field texts to the final research text (Clandinin, 2013).

${ }^{3}$ Caine, Estefan, and Clandinin (2013) asserte: “Often our understanding as narrative inquirers does not come instantaneously, or quickly, or by engaging in clever analysis. Instead our understanding deepens as we retell and relive our lived stories over time, place, and social contexts” (p. 581). My experience has certainly mirrored this sense of deepening rather than an epiphanal sense of suddenly seeing what was unclear before. This deepening of understanding occurs as part of the process of the relational research that is narrative inquiry. 